\title{
IMPLEMENTING CONTEXTUAL TEACHING AND LEARNING APPROACH TO IMPROVE STUDENTS' CONCEPTUAL UNDERSTANDING ON MATHEMATICS
}

\author{
Kasmiati \\ SD Negeri 002 Sungai Salak, Tempuling, Indonesia \\ kasmia878@gmail.com
}

\begin{abstract}
This research was motivated by the students' low understanding on the concepts and the students' difficulty in linking the knowledge to their daily life. Implementing contextual teaching and learning approach was expected to improve students' conceptual understanding. This research was a classroom action research conducted to third grade students at SDN Negeri 002 Sungai Salak, Kecamatan Tempuling. The research was conducted in the even semester of the academic year 2018-2019. The instrument was a concept understanding test. The results showed that the average score of students' conceptual understanding in cycle I was 68.43 with sufficient category. Then, the classical completeness was $56.25 \%$. In cycle II, the average score of the students' conceptual understanding was 72.81 with classical completeness reaching 93.75\%. Based on the research results, it was concluded that contextual teaching and learning approach improved the students' conceptual understanding at grade III SD Negeri 002 Sungai Salak, Kecamatan Tempuling.
\end{abstract}

\section{IMPLEMENTASI PENDEKATAN CONTEXTUAL TEACHING AND LEARNING UNTUK MENINGKATKAN PEMAHAMAN KONSEP MATEMATIKA SISWA}

\section{ABSTRAK}

Penelitian ini dilatarbelakangi oleh rendahnya pemahaman konsep siswa dan kesulitan siswa dalam mengaitkan pengetahuan yang mereka miliki dengan kehidupan di lingkungannya sehari-hari. Melalui penerapan pendekatan contextual teaching and learning diharapkan dapat meningkatkan pemahaman konsep siswa. Penelitian ini merupakan penelitian tindakan kelas yang dilakukan pada siswa kelas III SDN Negeri 002 Sungai Salak Kecamatan Tempuling. Pelaksanaan penelitian ini pada semester genap tahun ajaran 2018-2019. Instrumen yang digunakan adalah tes pemahaman konsep. Hasil penelitian menunjukkan pada siklus I pemahaman konsep siswa memiliki rata-rata 68.43 dengan kategori cukup dan ketuntasan klasikal sebesar $56.25 \%$. Pada siklus II pemahaman konsep siswa memiliki rata-rata sebesar 72.81 dengan ketuntasan klasikal mencapai 93.75\%. Berdasarkan hasil penelitian dapat disimpulkan bahwa penerapan pendakatan contextual teaching and learning dapat meningkatkan pemahaman konsep siswa kelas III SD Negeri 002 Sungai Salak Kecamatan Tempuling.

Kata Kunci: contextual teaching and learning, pemahaman konsep, matematika

\begin{tabular}{|c|c|c|}
\hline Submitted & Accepted & Published \\
\hline 31 Mei 2021 & 19 Juli 2021 & 29 Juli 2021 \\
\hline
\end{tabular}

\begin{tabular}{|l|l|c|c|}
\hline Citation & $:$ & $\begin{array}{r}\text { Kasmiati, K. (2021). Implementing Contextual Teaching and Learning Approach to Improve Students' Conceptual } \\
\text { Understanding on Mathematics. Jurnal PAJAR (Pendidikan dan Pengajaran), 5(4), 1108-1115. DOI : } \\
\text { http://dx.doi.org/10.33578/pir.v5i4.8432. }\end{array}$ \\
\hline
\end{tabular}

\section{PENDAHULUAN}

Salahsatu pelajaran yang penting untuk dipahami adalah matematika, karena matematika sangat diperlukan dalam semua disiplin ilmu. Untuk itu diperlukan upaya baik dari pemerintah selaku pembuat kebijakan, juga bagi guru sebagai ujung tombak pendidikan di sekolah yang berhubungan langsung dengan siswa. Guru harus senantiasa berupaya memahami kendala dan permasalahan yang dialami siswa serta menyiapkan suatu metode untuk dapat memecahkan masalah yang dihadapi siswa.
Sebagian besar siswa tidak mampu memahami dan mengaitkan pengetahuan yang diperoleh di kelas untuk dipergunakan atau dimanfaatkan dalam kehidupan di lingkungannya. Kemampuan pemahaman matematika adalah kemampuan mengklasifikasi objek, menginterpretasi gagasan atau konsep, dan menyatakan kembali konsep matematika dengan bahasa sendiri (Muna dan Afriansyah, 2016). Pada hakikatnya siswa tidak mempelajari matematika di sekolah semata yang hanya mengenal, 
mempelajari, namun tidak begitu memahami sehingga seiring waktu siswa melupakan materi yang dipelajari.

Permasalahan di lapangan saat ini terkhusus pada kelas III SDN 002 Sungai Salak Kecamatan Tempuling Kabupaten Indragiri Hilir ada kecendrungan bahwa pemahaman siswa pada pelajaran matematika masih kurang. Hal ini dibuktikan dari skor matematika siswa pada ujian akhir semester genap tahun 2018-2019 sebelumnya memiliki skor rata-rata 67 , sedangkan skor ideal yang diharapkan adalah 100 . Skor siswa ini juga belum mampu mencapai nilai kriteria ketuntasan minimum (KKM) yang ditetapkan sekolah untuk pelajaran matematika yakni 70 .

Seyogyanya siswa diharapkan dapat memahami dan mengaplikasikan pengetahuan dan keterampilan yang diperoleh di sekolah untuk memecahkan masalah yang ada di kehidupan nyata. Hal ini sesuai dengan Soedjadi dalam Atika (2021) bahwa tujuan umum diberikan pelajaran matematika di pendidikan dasar adalah agar siswa menggunakan matematika dan memiliki pola pikir matematika dalam kehidupan sehari-hari. Untuk dapat mewujudkan tujuan itu maka guru dapat menerapkan pendekatan kontekstual.

Beberapa penelitian yang telah mengkaji penerapan pendekatan contextual teaching and learning dalam meningkatkan kemampuan pemahaman konsep dari tahun ke tahun dilakukan oleh Sipayung (2018), Pujiati (2018) dan Akmil (2012). Dalam penelitian Latipah dan Afriansyah (2018) menunjukkan keberhasilan penerapan pembelajaran CTL terhadap peningkatan pemahaman konsep matematika siswa.

Berdasarkan latar belakang tersebut diharapkan melalui penerapan pendekatan CTL dapat meningkatkan pemahaman konsep matematika siswa. Sehingga sesuai tujuan penelitian ini agar siswa memperoleh dan peningkatan pemahaman yang baik atas konsep yang dipelajari melalui penerapan pendekatan CTL yang dilakukan peneliti.

\section{KAAJIAN TEORETIS \\ Contextual Teaching and Learning}

Pembelajaran kontekstual membuat siswa memiliki kemampuan untuk menghubungkan konsep-konsep teoretis dengan konteks kehidupan keseharian untuk menemukan makna yang berarti (Johnson, 2007). Senada dengan yang dikemukakan Sofiany (2016) bahwa pembelajaran dengan pendekatan kontekstual adalah pembelajaran yang mengambil (menstimulasikan, Menceritakan, berdialog, atau tanya jawab) kejadian pada dunia nyata kehidupan sehari-hari yang dialami siswa kemudian diangkat ke dalam konsep yang dibahas. Teori tersebut didukung oleh hasil penelitian yang dilakukan oleh Mulyani (2013). Selain itu, model pembelajaran kontekstual mengandung integrasi nilai-nilai karakter dalam pelajaran matematika (Maryati dan Priatna, 2017).

Gambaran sederhana tentang penerapan pendekatan contextual teaching and learning dalam proses pembelajaran menekankan pada tujuh komponen (Adirakasiwi, 2018), yakni: konstruktivisme (constructivism), bertanya (questioning), menemukan (inquiry), masyarakat belajar (learning community), pemodelan (modelling), refleksi (reflection), dan penilaian sebenarnya (authentic assessment).

\section{Pemahaman Konsep Matematika}

Memahami konsep matematika adalah salah satu kompetensi dalam menjelaskan kaitan antar konsep dan menggunakan konsep maupun algoritma secara luwes, akurat, efisien, dan tepat dalam pemecahan masalah (Yuliani, 2018). Menurut Rasid (2016) sangat penting bagi siswa untuk memahami konsep yang diajarkan guru karena dengan memahami konsep dapat membantu siswa dalam proses mengingat dan membuat siswa menjadi lebih mudah dalam mengerjakan soal-soal matematika yang menggunakan banyak rumus. Salah satu ciri siswa telah memahami konsep adalah jika siswa mampu menjelaskan materi yang dipelajari dengan menggunakan bahasa sendiri. Lebih lanjut Effendi (2017) mengemukakan bahwa pemahaman konsep merupakan kemampuan siswa dalam menguasai sejumlah materi pelajaran dengan tidak hanya mengetahui atau mengingat namun juga mampu mengungkapkan kembali dalam bentuk lain yang mudah dimengerti, memberikan interpretasi data, dan mampu mengaplikasikan konsep yang sesuai dengan struktir kognitif yang dimilikinya. Berdasarkan 
pendapat tersebut dapat diartikan bahwa pemahaman konsep merupakan pemahaman siswa terhadap suatu konsep yang dipelajari dengan kemampuannya dalam menyetakan kembali suatu konsep dengan bahasa yang mudah dipahaminya serta mampu memberikan contoh maupun representasi konsep dalam bahasa sendiri.

Indikator yang menunjukkan pemahaman konsep antara lain (Sari, 2017): 1) menyatakan ulang sebuah konsep; 2) mengklasifikasikan objekobjek menurut sifat-sifat tertentu (sesuai dengan konsepnya); 3) memberikan contoh dan non contoh dari konsep; 4) menyajikan konsep dalam berbagai bentuk representasi matematis; 5) syarat perlu atau syarat cukup suatu konsep; 6) menggunakan atau memanfaatkan, dan memilih prosedur atau operasi tertentu; dan 7) mengaplikasikan konsep atau algoritma pemecahan masalah. Dalam penelitian ini, indikator yang digunakan untuk diteliti hanya indikator 1 sampai 4 saja dengan pertimbangan kebutuhan penelitian.

\section{METODE PENELITIAN}

Jenis penelitian ini merupakan penelitian tidakan kelas (PTK) dimana dalam penelitian ini mencermati kegiatan pembelajaran yang sengaja dimunculkan dan terjadi dalam sebuah kelas
(Arikunto, 2010). Pelaksanaan penelitian ini bertempat di SD Negeri 002 Sungai Salak pada siswa kelas III yang berjumlah 32 siswa dimana terdapat 16 laki-laki dan 16 perempuan. Waktu penelitian ini adalah pada semester genap tahun ajaran 2018-2019 bulan Februari sampai Maret 2019. Penelitian tindakan kelas memiliki siklus pembelajaran yang berkesinambungan, pada setiap siklus memiliki tahapan perencanaan, tahapan pelaksanaan, tahapan obsevasi, dan tahapan refleksi.

Teknik pengumpulan data menggunakan tes untuk mengukur pemahaman konsep siswa berupa tes berbentuk pilihan ganda. Teknik yang digunakan untuk menganalisis data dalam menentukan persentase ketuntasan belajar siswa menggunakan rumus sesuai Rafika (2016) berikut:

a) Daya serap individu

$$
\begin{aligned}
& \text { daya serap individu } \\
& =\frac{\text { perolehan skor siswa }}{\text { skor maksimal tes }} \times 100 \%
\end{aligned}
$$

Untuk menentukan klasifikasi dari nilai rata-rata pemahaman konsep siswa, maka ditetapkan berdasarkan kriteria berikut ini:

Tabel 1. Kategori Pemahaman Konsep Siswa

\begin{tabular}{ccc}
\hline No. & Rentang Nilai & Kategori \\
\hline 1. & $90-100$ & Baik Sekali \\
2. & $70-89$ & Baik \\
3. & $50-69$ & Cukup \\
4. & $30-49$ & Kurang \\
5. & $0-29$ & Sangat Kurang \\
\hline
\end{tabular}

\section{a) Ketuntasan belajar klasikal}

persentase ketuntasan klasikal $=\frac{\text { jumlah siswa yang tuntas }}{\text { total siswa }} \times 100 \%$

Indikator keberhasilan penelitian tindakan kelas ini dapat dilihat dari beberapa tindakan yang diperoleh dalam pembelajaran. Nilai rata-rata pemahaman konsep siswa sesuai standar di sekolah yang ditetapkan dalam KKM adalah 70. Adapun secara klasikal ketuntasan belajar siswa sebanyak $90 \%$ dari jumlah siswa mampu mencapai atau menuntaskan pembelajaran dengan kategori baik.

\section{HASIL DAN PEMBAHASAN}

Penelitian ini dilakukan sebagai upaya untuk meningkatkan pemahaman konsep siswa melalui penerapan pendekatan contextual teaching and learning. Hasil penelitian pada siklus I masih menunjukkan hasil yang belum memuaskan. Secara lebih rinci hasil tes pada siklus 1 disajikan pada tabel berikut: 
Tabel 2. Rekapitulasi Hasil Tes Pemahaman Konsep Siswa Siklus I

\begin{tabular}{ccc}
\hline Variabel & Skor & Kategori \\
\hline Nilai Tertinggi & 80 & \\
Nilai Terendah & 45 & \\
Rata-rata & 68.43 & Cukup \\
\hline
\end{tabular}

Berdasarkan tabel 2 diketahui bahwa nilai tertinggi yang diperoleh siswa adalah 80 dan nilai terendah adalah 45 . Rata-rata nilai siswa adalah 68.43 yang masuk dalam kategori cukup. Nilai ini tentu belum sesuai dengan standard KKM yang ditetapkan oleh sekolah yakni 70. Adapun sebaran nilai pemahaman konsep yang diperoleh siswa secara rinci disajikan pada tabel berikut:

Tabel 3. Sebaran Nilai Siswa Berdasarkan Klasifikasi Nilai Siklus I

\begin{tabular}{ccc}
\hline Rentang Nilai & Jumlah Siswa & Persentase \\
\hline $90-100$ & 0 & $0 \%$ \\
$70-89$ & 18 & $56.25 \%$ \\
$50-69$ & 13 & $40.62 \%$ \\
$30-49$ & 1 & $3.12 \%$ \\
$0-29$ & 0 & $0 \%$ \\
\hline
\end{tabular}

Tabel 3 menunjukkan bahwa rentang nilai siswa berada pada kategori menengah dimana terdapat 18 siswa yang memiliki rentang nilai antara $70-89,13$ siswa memperoleh nilai pada rentang 50 - 69, dan 1 siswa memperoleh nilai pada rentang 30 - 49. Tidak ada siswa yang memperoleh nilai pada rentang sangat rendah ataupun sangat tinggi. Secara klasikal, ketuntasan belajar siswa pada siklus I dapat dilihat pada tabel berikut:

Tabel 4. Ketuntasan Belajar Siswa Siklus I

\begin{tabular}{cccc}
\hline No. & Ketuntasan Belajar & Jumlah Siswa & \\
& Tuntas $(\geq 70)$ & 18 & Persentase \\
\hline 1. & Belum Tuntas $(<70)$ & 14 & $56.25 \%$ \\
2. & Jumlah & 32 & $43.75 \%$ \\
& & $100 \%$ \\
\hline
\end{tabular}

Berdasarkan tabel 4 diketahui bahwa sebanyak 14 siswa belum mampu menuntaskan pembelajaran atau sebesar $43.75 \%$ belum mencapai KKM yang ditetapkan sekolah. Terdapat 18 siswa mampu menuntaskan pembelajaran dengan baik, artinya sebesar $56.25 \%$ siswa mencapai KKM yang ditetapkan oleh sekolah. Namun demikian hasil ini belum sesuai harapan penelitian karena peneliti berharap sebesar $90 \%$ siswamemiliki pemahaman konsep yang baik dan melebihi KKM yang ditetapkan.

Pemahaman konsep siswa pada siklus I khususnya pada kemampuan menyatakan ulang sebuah konsep memiliki persentase sebesar 58.12, ini berarti termasuk dalam kategori cukup. Menurut Febriani (2019) pemahaman konsep merupakan kemampuan siswa dalam menyampaikan atau menguraikan dan menjelaskan dari bahasa, dengan bahasa sendiri serta mampu menerapkan konsep tersebut pada sebuah permasalahan.

Pada aspek mengklasifikasikan objek mendapat nilai rata-rata 70 , ini termasuk dalam kategori baik. menurut Ginsburg dalam Ulandari (2018) supaya siswa mampu mengklasifikasikan atau menyortir benda mereka harus memahami 
konsep "saling memiliki kesamaan atau keserupaan" dan "perbedaan". Ketika siswa sudah mampu memahami hal tersebut maka akan mudah dalam mengklasifikasikan objek. Klasifikasi tidak hanya didasarkan pada pengelompokan warna, bentuk, dan ukuran saja, melainkan juga dapat didasarkan pada ciri-ciri yang sama, jenis yang sama, ataupun kombinasi dari kategori tersebut.

Pada aspek memberikan contoh dan non contoh dari konsep, siswa memperoleh nilai rata-rata 63.12 yang termasuk dalam kategori cukup. Dengan serangkaian contoh bahasa yang umum digunakan dalam kelas matematika, siswa bisa menggambarkan proses matematika, membaca dan menafsirkan notasi dan mendefinisikan istilah dalam matematika. Hadirnya contoh kontekstual yang ada dalam pembelajaran dapat meningkatkan pemahaman konsep siswa (Boulet, 2007).
Pada aspek menyajikan konsep dalam berbagai bentuk representasi matematis siswa mampu memperoleh nilai yang baik sekali yakni 82.5. Hal ini mencerminkan siswa sudah mampu merepresentasikan suatu konsep matematika dalam bentuk lain misal seperti membuat simbol, membuat rumusan berdasarkan konsep yang disajikan.

Adapun hasil tes pemahaman konsep siswa pada siklus II mengalami peningkatan yang signifikan. Siswa mampu mencapai nilai KKM yang ditetapkan dan secara klasikal memperoleh nilai yang baik dan mampu menuntaskan pembelajaran sesuai harapan yang diinginkan oleh peneliti. Berikut rekapitulasi hasil tes pemahaman konsep siswa pada siklus II:

Tabel 5. Rekapitulasi Hasil Tes Pemahaman Konsep Siswa Siklus II

\begin{tabular}{ccc}
\hline Variabel & Skor & Kategori \\
\hline Nilai Tertinggi & 85 & \\
Nilai Terendah & 60 & \\
Rata-rata & 72.81 & Baik \\
\hline
\end{tabular}

Berdasarkan tabel 5 tersebut di atas, dapat diketahui pemahaman konsep siswa pada siklus II memiliki rata-rata sebesar 72.81. Hasil ini sudah baik dan telah mencapai KKM yang ditetapkan oleh sekolah dan harapan penelitian. Nilai tertinggi yang diperoleh siswa adalah 85 dan nilai terendah adalah 60. Berdasarkan hasil ini pemahaman konsep siswa sudah sesuai yang diharapkan. Adapun sebaran nilai pemahaman konsep siswa pada siklus II disajikan pada tabel berikut:

Tabel 6. Sebaran Nilai Siswa Berdasarkan Klasifikasi Nilai Siklus II

\begin{tabular}{ccc}
\hline Rentang Nilai & Jumlah Siswa & Persentase \\
\hline $90-100$ & 1 & $3.12 \%$ \\
$70-89$ & 29 & $90.62 \%$ \\
$50-69$ & 2 & $6.25 \%$ \\
$30-49$ & 0 & $0 \%$ \\
$0-29$ & 0 & $0 \%$ \\
\hline
\end{tabular}

Berdasarkan tabel 6 diketahui bahwa tidak terdapat siswa yang memperoleh nilai pada rentang 0 - 29 dan $30-49$, ini berarti pemahaman siswa sudah baik karena tidak ada yang memperoleh nilai yang rendah. Pada rentang 50-69 terdapat 2 siswa, dengan persentase sebesar $6.25 \%$. Sebanyak 29 siswa memperoleh nilai pada rentang $70-89$ dengan persentase sebanyak $90.62 \%$. Kemudian ada 1 siswa yang mampu memperoleh nilai pada rentang $90-100$ yang berarti sebesar $3.12 \%$. Secara klasikal, ketuntasan belajar siswa dapat dilihat pada tabel berikut: 
Jurnal PAJAR (Pendidikan dan Pengajaran)

Volume 5 Nomor 3 April 2021 | ISSN Cetak : 2580 - 8435| ISSN Online : 2614 - 1337

DOI : http://dx.doi.org/10.33578/pjr.v5i4.8432

Tabel 7. Ketuntasan Belajar Siswa Siklus II

\begin{tabular}{|c|c|c|c|}
\hline \multirow{2}{*}{ No. } & \multirow{2}{*}{ Ketuntasan Belajar } & \multicolumn{2}{|c|}{ Jumlah Siswa } \\
\hline & & Jumlah & Persentase \\
\hline 1. & Tuntas $(\geq 70)$ & 30 & $93.75 \%$ \\
\hline 2. & $\begin{array}{c}\text { Belum Tuntas }(< \\
70)\end{array}$ & 2 & $6.25 \%$ \\
\hline & & 32 & $100 \%$ \\
\hline
\end{tabular}

Ketuntasan belajar siswa secara klasikal adalah sebesar $93.75 \%$ atau sebanyak 30 siswa mampu mencapai nilai KKM yang ditetapkan. Hal ini menunjukkan bahwa hampir seluruh siswa memiliki pemahaman konsep yang baik. Hanya terdapat 2 siswa yang belum mampu mencapai KKM yang ditetapkan. Hasil ini merefleksikan bahwa pemahaman konsep siswa sudah masuk dalam kategori baik.

\section{Pembahasan}

Pemahaman konsep siswa pada siklus I khususnya pada kemampuan menyatakan ulang sebuah konsep memiliki persentase sebesar 58.12, ini berarti termasuk dalam kategori cukup. Menurut Febriani (2019) pemahaman konsep merupakan kemampuan siswa dalam menyampaikan atau menguraikan dan menjelaskan dari bahasa, dengan bahasa sendiri serta mampu menerapkan konsep tersebut pada sebuah permasalahan.

Pada aspek mengklasifikasikan objek mendapat nilai rata-rata 70 , ini termasuk dalam kategori baik. menurut Ginsburg dalam Ulandari (2018) supaya siswa mampu mengklasifikasikan atau menyortir benda mereka harus memahami konsep "saling memiliki kesamaan atau keserupaan" dan "perbedaan". Ketika siswa sudah mampu memahami hal tersebut maka akan mudah dalam mengklasifikasikan objek. Klasifikasi tidak hanya didasarkan pada pengelompokan warna, bentuk, dan ukuran saja, melainkan juga dapat didasarkan pada ciri-ciri yang sama, jenis yang sama, ataupun kombinasi dari kategori tersebut.

Pada aspek memberikan contoh dan non contoh dari konsep, siswa memperoleh nilai ratarata 63.12 yang termasuk dalam kategori cukup. Dengan serangkaian contoh bahasa yang umum digunakan dalam kelas matematika, siswa bisa menggambarkan proses matematika, membaca dan menafsirkan notasi dan mendefinisikan istilah dalam matematika. Hadirnya contoh kontekstual yang ada dalam pembelajaran dapat meningkatkan pemahaman konsep siswa (Boulet, 2007).

Pada aspek menyajikan konsep dalam berbagai bentuk representasi matematis siswa mampu memperoleh nilai yang baik sekali yakni 82.5. Hal ini mencerminkan siswa sudah mampu merepresentasikan suatu konsep matematika dalam bentuk lain misal seperti membuat simbol, membuat rumusan berdasarkan konsep yang disajikan.

Pada siklus II, secara lebih rinci pada aspek menyatakan ulang sebuah konsep, siswa mampu memperoleh nilai rata-rata sebesar $61.87 \%$ yang merupakan kategori cukup. Menurut Cahyono (2012) interaksi antara siswa dan guru dapat meningkatkan pemahaman konsep matematika. Pengkaitan materi pelajaran dengan kehidupan nyata dapat berdampak positif terhadap hasil belajar siswa.

Pada aspek mengklasifikasikan objek memiliki rata-rata sebesar $75.62 \%$ yang masuk dalam kategori baik. Kemampuan mengklasifikasi sangat penting bagi siswa untuk memperluas pengetahuan mereka dan mendorong siswa untuk dapat mengamati benda-benda berbeda dan membantu anak memperoleh informasi baru (Juniati, 2020).

Kemampuan memberi contoh dan non contoh dari konsep memperoleh nilai rata-rata sebesar $70 \%$ yang merupakan kategori baik. Pada aspek representasi ke dalam bentuk lain memperoleh nilai rata-rata sebesar $83.75 \%$ yang termasuk dalam kategori baik. Hasil ini juga dibuktikan oleh Mei (2020). 


\section{SIMPULAN DAN REKOMENDASI}

Berdasarkan penelitian tindakan kelas yang telah dilakukan dapat disimpulkan penerapan pendekatan contextual teaching and learning dapat meningkatkan pemahaman konsep siswa kelas III SDN 002 Sungai Salak Kecamatan Tempuling. Hal ini terlihat pada aspek pemahaman konsep siswa dimana siswa mampu menyatakan ulang sebuah konsep, memberikan contoh dan non contoh, mengklasifikasi objek, dan merepresentasikan dalam bentuk lain.

Diharapkan penelitian selanjutnya dapat mengkaji aspek pemahaman konsep lainnya agar dapat melihat sejauh mana pengaruh dari pendekatan contextual teaching and learning terhadap pemahaman konsep siswa. Selain itu juga perlu diperhatikan bagaimana cara guru dalam menerapkan setiap tahapan yang ada dalam CTL yang diterapkan dalam kegiatan pembelajaran di kelas.

\section{DAFTAR PUSTAKA}

Adirakasiwi, A, G., Warmi, A., dan Imami, A, I. (2018). Penerapan Pendekatan Kontekstual Terhadap Penguasaan Konsep Dasar Materi Volume Benda Putar. JPPM (Jurnal Penelitian dan Pembelajaran Matematika), 11 (1), 1-10.

Akmil, A, R., Armiati., dan Rizal, Y. (2012). Implementasi CTL dalam Meningkatkan Pemahaman Konsep Matematika Siswa. Jurnal Pendidikan Matematika, 1 (1), 2429.

Arikunto, S. (2010). Prosedur Penelitian. Jakarta: Rineka Cipta.

Atika. (2021). Penerapan Model Pembelajaran Kontekstual untuk Meningkatkan Pemahaman Konsep Matematika pada Pokok Bahasan Bangun Ruang pada Siswa SMA Negeri 7 Kota Bengkulu. Jurnal Bioeduscientific PPs UNMUH Bengkulu, 2 (1), 83-92.

Boulet, G. (2007). How Does Language Impact the Learning of Mathematics? Let Me Count the Ways". Journal of Teaching and Learning, 5 (1), 1-12.

Cahyono, A, N. (2012). Virtualmatriks: A Conceptual Mathematization Process in
Virtual Learning Environtment. The Online Journal of Science and Technology, 2 (3), 71-76.

Effendi, K, N. (2017). Pemahaman Konsep Siswa Kelas VIII pada Materi Kubus dan Balok. Pasundan Journal of Research in Mathematics Learning and Education, 2 (2), 87-94.

Febriani, P., Widada, W., dan Herawaty, D. (2019). Pengaruh Pembelajaran Matematika Realistik Berbasis Etnomatematika Terhadap Kemampuan Pemahaman Konsep Matematika Siswa SMA Kota Bengkulu. Jurnal Pendidikan Matematika Raflesia, 4 (2), 120-135.

Johnson, E, B. (2007). Contextual Teaching \& Learning Menjadikan Kegiatan Belajar Mengajar Mengasyikkan dan Bermakna. Bandung: Penerbit MLC.

Juniati, W., dan Hazizah, N. (2020). Permainan Sorting Color dalam Meningkatkan Kemampuan Klasifikasi Pra-Matematika di Taman Kanak-kanak Islam Budi Mulia Padang. Jurnal Golden Age, Universitas Hamzanwadi, 4 (1), 143-151.

Latipah, E, D, P., dan Afriansyah, E, A. (2018). Analisis Kemampuan Koneksi Matematis Siswa Menggunakan Pendekatan Pembelajaran CTL dan RME. Jurnal Matematika, 17 (1), 1-12.

Maryati, I., dan Priatna, N. (2017). Integrasi Nilainilai Karakter Matematika Melalui Pembelajaran Kontekstual. Mosharafa: Jurnal Pendidikan Matematika, 6 (3), 333 344.

Mei, M, F., Seto, S, B., dan Wondo, M, T, S. (2020). Pembelajaran Kontekstual Melalui Permainan Kelereng pada Siswa Kelas III SD untuk Meningkatkan Pemahaman Konsep Perkalian. JUPIKA: Jurnal Pendidikan Matematika Universitas Flores, 3 (2), 61-70.

Mulyani, H, R, A. (2013). Pengaruh Penerapan Pembelajaran Kontekstual Terhadap Peningkatan Penguasaan Konsep Bahan Kimia dalam Kehidupan Sehari-hari dan Keterampilan Berpikir Kritis Siswa Kelas 
Jurnal PAJAR (Pendidikan dan Pengajaran)

Volume 5 Nomor 3 April 2021 | ISSN Cetak : 2580 - 8435 | ISSN Online : 2614 - 1337

DOI : http://dx.doi.org/10.33578/pjr.v5i4.8432

VIII SMP Negeri 4 Metro. Jurnal Bioedukasi, 4 (2), 114-121.

Muna, D, N., dan Afiansyah, E, A. (2016). Peningkatan Kemampuan Pemahaman Matematis Siswa Melalui Pembelajaran Kooperatif Teknik Kancing Gemerincing dan Number Head Together. Mosharafa: Jurnal Pendidikan Matematika, 5 (2), 169 176.

Pujiati., Kanzunnudin, M., dan Wanabuliandari, S. (2018). Penerapan Contextual Teaching and Learning Berbantu Blok Pecahan untuk Peningkatan Pemahaman Konsep Siswa. ANARGYA: Jurnal Ilmiah Pendidikan Matematika, 1 (1), 122-129.

Rafika. (2016). Upaya Meningkatkan Pemahaman Konsep Gaya dengan Menggunakan Metode Eksperimen Siswa Kelas IV SDN 1 Siwalempu. Jurnal Kreatif Tadulako Online, 4 (2), 10-24.

Rasid, S., Hairun, Y., dan Afandi, A. (2016). Penerapan Model Pembelajaran Team Assisted Individuallization (TAI) Ditinjau dari Kemampuan Pemahaman Matematis Siswa pada Materi Trigonometri. DeltaPi: Jurnal Matematika dan Pendidikan Matematika, 5 (1), 1-23.

Sari, P. (2017). Pemahaman Konsep Matematika Siswa pada Materi Besar Sudut Melalui Pendekatan PMRI. Jurnal Gantang, 2 (1), 41-50.

Sipayung, A. (2018). Meningkatkan Pemahaman Konsep Matematika tentang Sifat-sifat Bangun Ruang Sederhana Melalui Contextual Teaching and Learning. Mosharafa: Jurnal Pendidikan Matematika, 7 (3), 401-412.

Sopiany, H, N., Hijjah, I, S. (2016). Penggunaan Strategi TTW (Think-Talk-Write) dengan Pendekatan Kontekstual dalam Meningkatkan Kemampuan Pemecahan Masalah dan Disposisi Matematis Siswa MTsN Rawamerta Karawang. JPPM (Jurnal Penelitian dan Pembelajaran Matematika), 9 (2), 268-276.

Ulandari, V., Saparahayuningsih, S., dan Yulidesni. (2018). Meningkatkan Kemampuan Klasifikasi Melalui Bermain
Konstruktif Sifat Padat. Jurnal Ilmiah Potensia, 3 (1), 72-77.

Yuiani, E, N., Zulfah., dan Zulhendri. (2018). Kemampuan Pemahaman Konsep Matematis Siswa Kelas VIII SMPN 1 Kuok Melalui Model Pembelajaran Kooperatif Tipe Group Investigation. Jurnal Cendekia: Jurnal Pendidikan Matematika, 2 (2), 91-100. 